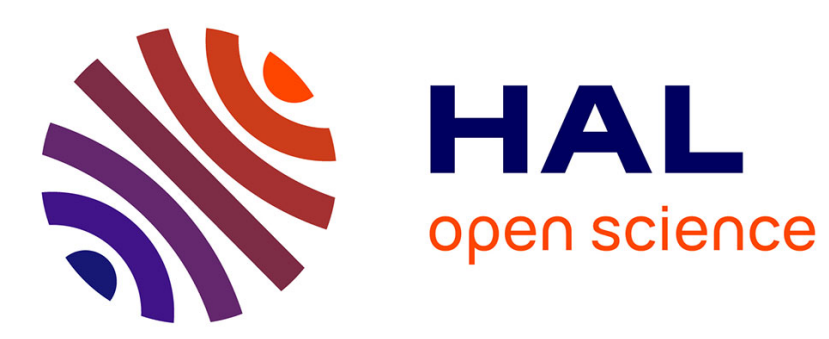

\title{
Macrofaunal reworking activities and hydrocarbon redistribution in an experimental sediment system
}

Sarah Caradec, Vincent Grossi, Stefan Hulth, Georges Stora, Franck Gilbert

\section{To cite this version:}

Sarah Caradec, Vincent Grossi, Stefan Hulth, Georges Stora, Franck Gilbert. Macrofaunal reworking activities and hydrocarbon redistribution in an experimental sediment system. Journal of Sea Research (JSR), 2004, vol. 52, pp. 199-210. 10.1016/j.seares.2004.02.002 . hal-00757304

\section{HAL Id: hal-00757304 https://hal.science/hal-00757304}

Submitted on 26 Nov 2012

HAL is a multi-disciplinary open access archive for the deposit and dissemination of scientific research documents, whether they are published or not. The documents may come from teaching and research institutions in France or abroad, or from public or private research centers.
L'archive ouverte pluridisciplinaire HAL, est destinée au dépôt et à la diffusion de documents scientifiques de niveau recherche, publiés ou non, émanant des établissements d'enseignement et de recherche français ou étrangers, des laboratoires publics ou privés. 


\title{
Macrofaunal reworking activities and hydrocarbon redistribution in an experimental sediment system
}

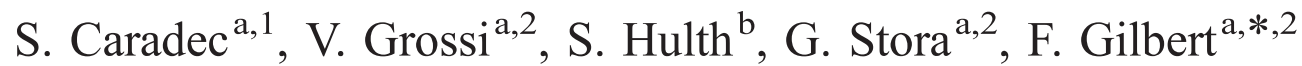

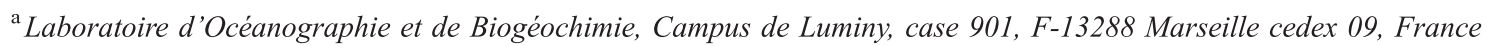 \\ ${ }^{\mathrm{b}}$ Department of Chemistry, Göteborg University, SE-412 96 Göteborg, Sweden
}

\begin{abstract}
The influence of macrofaunal reworking activities on the redistribution of particle associated hydrocarbon compounds (HC) was experimentally investigated. Two distinct hydrocarbon mixtures adsorbed on montmorillonite particles $(<4 \mu \mathrm{m}$ diameter) were added to the surface and deeper $(2.5 \mathrm{~cm})$ sediment layers. For comparison, luminophores $(100-160 \mu \mathrm{m}$ diameter $)$ were added in the two deposit layers. At the start of the experiment, four macrobenthic species (the bivalve Abra nitida, the polychaete Scalibregma inflatum, and the echinoderms Amphiura filiformis and Echinocardium cordatum) were added to the sediment surface. The macrofauna added rapidly transferred $\mathrm{HC}$ from the surface sediment down to $\sim 5 \mathrm{~cm}$ depth by both continuous (biodiffusion) and non-continuous (biotransport) transport. Hydrocarbon compounds initially added to the deeper sediment layer were only subject to biodiffusion-like transport. Apparent biodiffusion coefficients $(D b)$ quantified by using a 1-D model were between 0.5 and $8.4 \times 10^{-3} \mathrm{~cm}^{2} \mathrm{~d}^{-1}$, and biotransport coefficients $(r)$ ranged from 2.0 to $27.6 \times 10^{-3} \mathrm{~d}^{-1}$. Thus, the four species studied did not have the same effect on particle redistribution and, consequently, on $\mathrm{HC}$ repartition in the sediments. E. cordatum was the most efficient reworker. The present study demonstrated the importance of particle size selectivity by benthic fauna, and verified that macrofaunal reworking activities may redeposit sediment from deeper sediment layers on the sediment surface. Both processes have obvious implications for rates and pathways during organic matter mineralisation in marine sediments.
\end{abstract}

Keywords: Bioturbation; Hydrocarbons; Sediment reworking; Macrofauna; Gullmar Fjord

\section{Introduction}

Macrofaunal particle reworking and irrigation of overlying water and pore water (bioturbation) are

\footnotetext{
* Corresponding author.

E-mail address: gilbert@com.univ-mrs.fr (F. Gilbert).

1 Present address: School of Chemistry, Organic Geochemistry Unit, University of Bristol, Cantock's Close, Bristol BS8 1TS, UK.

${ }^{2}$ Present address: Laboratoire de Microbiologie, Géochimie et Ecologie Marines, COM-OSU, Université de la Méditerranée, Campus de Luminy, case 901, F-13288 Marseille cedex 09, France.
}

recognised as quantitatively and qualitatively important processes during early diagenesis of organic material (OM) in benthic marine environments (e.g. Aller et al., 2001; Reise, 2002). For example, burrowing, tube construction, feeding and ventilation activities redistribute fluids and particles, alter oxic/anoxic boundaries, and modify local environmental conditions for microbial activities (Aller, 2001). As a result, solute and particle fluxes across the sediment-water interface, and rates and pathways during OM mineralisation may be significantly different in sediments with benthic macofauna compared to those without 
(Osinga et al., 1997; Sun et al., 1999; Berg et al., 2001; Kristensen, 2001; Gilbert et al., 2003a). Laboratory experiments using individual species of macrofauna (Kristensen and Blackburn, 1987; François et al., 1999; Ingalls et al., 2000) have confirmed their importance for the fate of sedimentary OM. However, the net effect on the overall fate of organic material is not always evident from experimental observations and is often difficult to predict from bulk measurements, e.g. of macrofauna biomass. For example, while natural benthic assemblages have been demonstrated to enhance the reactivity of recently deposited lipid biomarkers (Webb and Montagna, 1993; Bianchi et al., 2000; Middelburg et al., 2000; Grossi et al., 2003), there are numerous reports that animal activities actually slow down the degradation of sedimented OM (Blair et al., 1996; Van de Bund et al., 2001; Josefson et al., 2002).

Studies on the relation between bioturbation and overall fate of OM in marine sediments have generally focused on how benthic animals affect the fate of organic tracers deposited on the sediment surface (e.g., Gilbert et al., 1996; Sun et al., 1999), or how bioirrigation alters the availability of higher oxidants such as oxygen and removes toxic metabolites (Andersen and Kristensen, 1992; Hulthe et al., 1998; Kristensen and Holmer, 2001; Gilbert et al., 2003a). Periodic re-exposition to oxygen of already buried material is an important mechanism to support rates and extent and organic matter degradation (Hulthe et al., 1998). Detailed and accurate knowledge on how individual macrofaunal species and communities influence particle and solute redistribution in surface deposits is therefore essential for understanding the fate of OM in marine sediments. Indeed, each macrofaunal species induces a particular particle and solute transport mechanism depending on its functionality (i.e. feeding mode and overall behaviour; François et al., 2001).
To investigate how individual species of macrofauna with a distinct functionality influence $\mathrm{OM}$ redistribution in surface sediments, we carried out an experiment with four macrobenthic species from the Alsbäck trough (the Gullmar Fjord, western Sweden): the bivalve Abra nitida, the polychaete Scalibregma inflatum, and the echinoids Amphiura filiformis and Echinocardium cordatum. The experimental set-up was specifically designed to study both upward and downward movements of organic tracers (hydrocarbons) and inert particulate tracers (luminophores). Modelling of tracer distributions allowed us to calculate and compare continuous and non-continuous mixing coefficients $(D b, r)$ for the different macrobenthic species. A comparison between hydrocarbon and particulate tracers was made in terms of particle selection by macrofauna.

\section{Material and methods}

\subsection{Sampling and experimental set-up}

In July 2001, sediment for sediment-water incubations was collected at the Alsbäck site $(120 \mathrm{~m})$ in the Gullmar Fjord (western Sweden) using a box-corer $(0.5 \times 0.5 \mathrm{~m})$. Surface $(0-9 \mathrm{~cm})$ and deeper $(9-40$ $\mathrm{cm})$ sediment layers were removed and sieved $(0.1$ and $0.3 \mathrm{~cm}$ mesh, respectively) separately. An experimental sediment geometry was reconstructed in a large $(0.80 \times 0.38 \mathrm{~m})$ plastic tank, where $6 \mathrm{~cm}$ of the sieved and homogenised surface sediment was applied on top of $18 \mathrm{~cm}$ deeper sediment (Fig. 1). Filtered surface water was allowed to continuously circulate above the sediment in a flow-through system. This system was used for pre-incubation at $10^{\circ} \mathrm{C}$ for 1 month.

In August 2001, four macrofaunal species, typical inhabitants of the Gullmar Fjord (Josefson et al.,

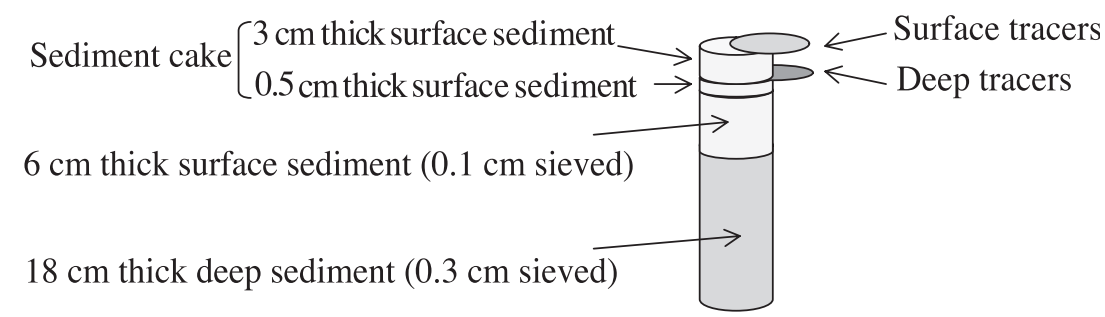

Fig. 1. Geometry of the reconstructed experimental sediments before the introduction of macrofaunal species. 
2002), the bivalve Abra nitida, the polychaete Scalibregma inflatum and the echinoderms Amphiura filiformis and Echinocardium cordatum, were collected with a box-corer $(0.5 \times 0.5 \mathrm{~m})$. Individuals to be used in the experiment were sorted and placed in sediment aquaria inside a running-water system until the start of the experiment.

Two mixtures of tracers (synthetic hydrocarbons and luminophores) were prepared. The first mixture, later to be deposited on the sediment surface (surf$\mathrm{HC}$ and surf-lum), contained phytane (3,7,11,15-tetramethylhexadecane), squalane $(2,6,10,15,19,23$-hexamethyltetracosane; Aldrich) and hexatriacontane (Aldrich) $(20 \mathrm{mg} / \mathrm{g}$ of each hydrocarbon adsorbed on montmorillonite $<4 \mu \mathrm{m}$ ), and green luminophores $(100-160 \mu \mathrm{m}, 1.8 \mathrm{~g})$. Phytane was obtained in the laboratory after deshydratation of phytol (Interchim) and further catalytic hydrogenation. The second mixture contained pristane $(2,6,10,14$-tetramethylpentadecane; Aldrich), dodecylcyclohexane (TCI-EP) and dotriacontane (Aldrich) and red luminophores (100$160 \mu \mathrm{m}, 1.8 \mathrm{~g})$. This latter HC mixture was later included at $3.5 \mathrm{~cm}$ depth in the sediment (deep-HC and deep-lum). $20 \mathrm{mg} / \mathrm{g}$ of each hydrocarbon was adsorbed on montmorillonite particles $(<4 \mu \mathrm{m})$ before being included in the two $\mathrm{HC}$ mixtures. The background content of $\mathrm{HC}$ was found to be insignificant (less than $0.1 \%$ of the added hydrocarbons).

In order to introduce the two hydrocarbon mixtures at two different depths in the reconstructed sediment cores, $3.5 \mathrm{~cm}$-thick sediment-hydrocarbon cakes were made (Fig. 1). A bottom sediment layer (initial sieved surface sediment; $0.5 \mathrm{~cm}$ height) was deposited on the bottom of cylindrical moulds $(3.5 \mathrm{~cm}$ height; $97 \mathrm{~mm}$ i.d.). Known quantities of the second HC-mixture were sprinkled on the sediment layer. Moulds were subsequently filled with $3 \mathrm{~cm}$ of sieved surface sediment. Known quantities of the first HC-mixture were sprinkled on the surface of the sediment cake, and the moulds were frozen. After removal of the overlying water, 15 sediment core tubes $(35 \mathrm{~cm}$ long; $98.8 \mathrm{~mm}$ i.d.) were carefully inserted into the sediment in the tank. The frozen sediment plugs with the $\mathrm{HC}$ mixtures were removed from the moulds and added to the surface sediment of the inserted cores (Fig. 1). The set-up was supplied with a continuous water-flow of aerated bottom water during a stabilisation period of $2 \mathrm{~d}$. Temperature was kept constant at $10^{\circ} \mathrm{C}$, close to the in situ temperature $\left(6^{\circ} \mathrm{C}\right.$ throughout the year).

Six individuals of each macrofaunal species were carefully removed from their aquaria and added separately to three replicate cores for each treatment. Including three control cores where no macrofauna was added, there were thus 15 cores in the incubation system. The animals were weighed individually $(A$. nitida $=0.234 \pm 0.051 \mathrm{~g}$, $S$. inflatum $=0.277 \pm 0.101$ g, A. filiformis $($ disc $)=0.033 \pm 0.009$ g, E. cordatum $=0.370 \pm 0.140 \mathrm{~g}, n=18$ ).

After $10 \mathrm{~d}$ of sediment-water incubation with a continuous supply of well-oxygenated bottom water with a composition close to that of ambient bottom water, the sediment cores were sliced into $0.5 \mathrm{~cm}$ layers from 0 to $4 \mathrm{~cm}$ depth, and then into $1 \mathrm{~cm}$ thick sections from $4 \mathrm{~cm}$ down to $18 \mathrm{~cm}$ depth. Sediment slices were freeze-dried and stored frozen before analysis.

\subsection{Analysis of tracers}

Each slice was homogenised and a sediment aliquot (5-20 g dry sediment) was extracted for lipids $(12 \mathrm{~h})$ using the extraction procedure with dichloromethane as solvent. Organic extracts were pre-concentrated by rotary evaporation and hydrocarbons were separated by column chromatography (silica gel; $3 \% \mathrm{H}_{2} \mathrm{O}$ ) with $n$-hexane $(50 \mathrm{~mL})$. Individual hydrocarbons were quantified by Gas Chromatography - Flame Ionization Detection (GC-FID HP6890 with a HP7683 autosampler. Separations were performed with a HP1 capillary column $(25 \mathrm{~m} \times 0.32 \mathrm{~mm}$ i.d., $0.17 \mu \mathrm{m}$ film thickness $)$ in splitless mode injection $\left(280^{\circ} \mathrm{C}\right)$ with Helium as the carrier gas. The temperature of the FID was $280^{\circ} \mathrm{C}$. The oven temperature programme was: $1 \mathrm{~min}$ at $60^{\circ} \mathrm{C}$, $20 \mathrm{~min}$ from 60 to $130^{\circ} \mathrm{C}, 4 \mathrm{~min}$ from 130 to $300^{\circ} \mathrm{C}$ and $10 \mathrm{~min}$ at $300^{\circ} \mathrm{C}$. Individual retention time of hydrocarbons was determined with single external standards. Heneicosane was used as an internal standard for quantification.

For each sediment slice, part of the sediment was used for luminophore quantification under UV light (Gérino et al., 1998).

\subsection{Data modelling}

The reaction-diffusion type model used in this paper to describe tracer redistributions following 
macrofaunal reworking is based on the general diagenetic equation (Berner, 1980):

$\frac{\partial C}{\partial t}=\frac{\partial}{\partial z}\left(D b \frac{\partial C}{\partial z}\right)+R(C)$

where $C$ is the concentration of the tracer, $t$ the time, $z$ the depth, $D b$ the apparent biodiffusion coefficient, and $R(C)$ the non-continuous displacement of tracer. The term $R(C)$ is defined as follows:

$$
\begin{aligned}
& R(C(z, t)) \\
& =\left\{\begin{array}{l}
\frac{r}{z_{2}-z_{1}} \int_{0}^{x_{1}} C(x, t) d x \text { if } \mathrm{z} \in\left[\mathrm{z}_{1} ; \mathrm{z}_{2}\right] \\
-r C(z, t) \text { if } \mathrm{z} \in\left[0 ; \mathrm{z}_{1}\right] \\
0 \text { if } \mathrm{z}>\mathrm{z}_{2}
\end{array}\right.
\end{aligned}
$$

where $z_{1}$ and $z_{2}$ define the upper and lower limits of the tracer redistribution, $\mathrm{x}$ and $\mathrm{z}$ are depth variables and the biotransport coefficient $(r)$ is the percentage of tracer that left the $\left[0, x_{1}\right]$ deposit and redistributed in the $\left[\mathrm{z}_{1}, \mathrm{z}_{2}\right]$ layer. The redistribution of tracer between $z_{1}$ and $z_{2}$ and the disappearance of tracer from the 0 $z_{1}$ layer are described by Eqs. (2a) and (2b), respectively. Eq. (2c) indicates that no tracer movement occurs below $\mathrm{z}_{2}$.

This displacement term was originally exemplified in a model describing gallery-diffusion of macrofaunal reworking (François et al., 2002). This biological reworking process describes the diffusive-like mixing of particles in the region of intense burrowing activity and the rapid transport of organic and inorganic material from the upper sediment layers to the lower regions of reworking (i.e. 'biotransport').

According to the experimental conditions, the following initial conditions were used:

$C(\mathrm{z}, 0)=\left\{\begin{array}{l}C_{0} \text { if } \mathrm{z} \in\left[\mathrm{x}_{1} ; \mathrm{x}_{2}\right] \\ 0 \text { else }\end{array}\right.$

where $\mathrm{x}_{1}$ is the maximum depth of continuous particle transport, and $\mathrm{x}_{2}$ is the maximum depth of noncontinuous particle transport.
Finally, a zero - flux Neuman boundary condition was considered:

$$
\frac{\partial C}{\partial z}(0, t)=\lim _{\mathrm{z} \rightarrow+\infty} \frac{\partial C}{\partial \mathrm{z}}(\mathrm{z}, t)=0
$$

The application of this bioturbation model to tracer redistributions allowed the quantification of two particle mixing coefficients: an apparent biodiffusion coefficient $D b$ and a biotransport coefficient $r$. The biodiffusion coefficient $D b$ takes into account the diffusion-like transport due to the activity of the organisms. We assume that the actual concentrationdependent diffusion of tracers is negligible. The biotransport coefficient $(r)$ represents a non-local mixing pattern associated with a biologically induced transfer of particles from one place to another in a discontinuous pattern, i.e. a non-continuous transport; Boudreau, 1986).

\subsection{Data analysis}

We used a Kruskal-Wallis test followed by mean comparison of Nemenyi (Zar, 1999) to validate even-

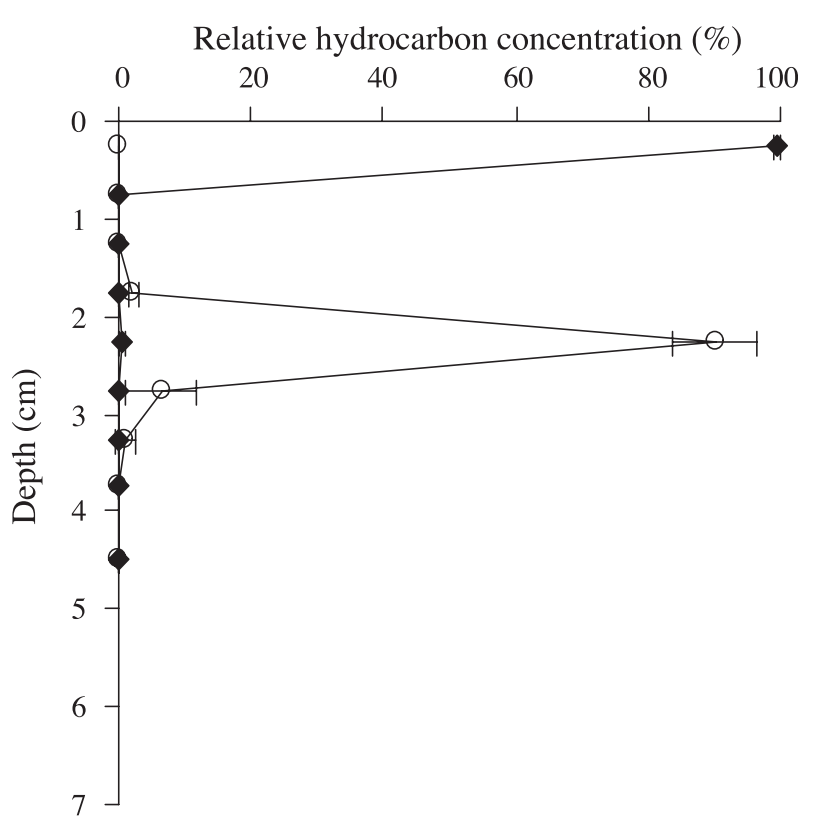

Fig. 2. Hydrocarbon depth profiles in control sediments without macrofauna. Full symbol: surface tracer (pristane); open symbol: deep tracer (phytane). Data are expressed in relative percentage of total tracer recovered at the end of the experiment and corrected for background concentration. 
tual differences between species. This test is normally applied to smaller data sets without normal probability distributions. It is a non-parametric equivalent to oneway ANOVA. Results were considered significant at $\mathrm{P}<0.05$ (Zar, 1999).

\section{Results}

Results presented in this paper are mainly focussed on the movement of hydrocarbon tracers due to macrofaunal activities. Quantification of luminophore mix-

Relative hydrocarbon concentration $(\%)$
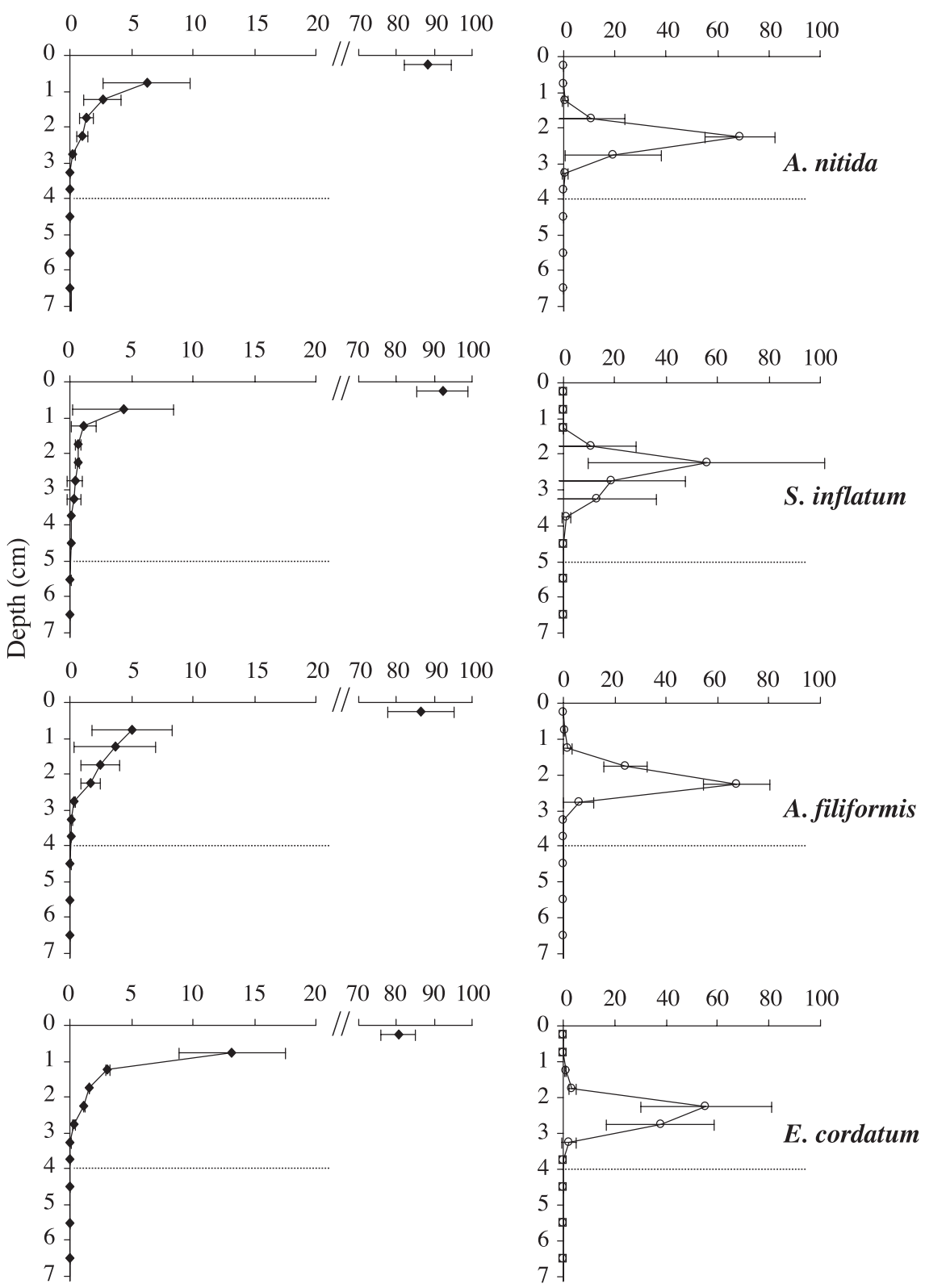

Fig. 3. Hydrocarbon depth profiles in experimental sediments inhabited by Abra nitida, Scalibregma inflatum, Amphiura filiformis and Echinocardium cordatum. Left: one surface tracer (pristane), right: one deep tracer (phytane). Data are expressed in relative percentage of total tracer recovered at the end of the experiment and corrected for background concentration (mean $\pm \mathrm{SD}, n=3$ for $A$. nitida and $S$. inflatum and $n=2$ for $A$. filiformis and E. cordatum due to a different sediment slicing for one core, $0.6 \mathrm{~cm}$ step instead of $0.5 \mathrm{~cm}$ step). Dotted lines represent the maximal reworked zones where more than $99 \%$ of the tracers were found. 
ing is only used for the comparison of tracer redistributions. A detailed study of the influence of the macrobenthic species on luminophore redistribution will be discussed elsewhere (Gilbert et al., ms in prep.).

\subsection{Tracer profiles}

After the $10 \mathrm{~d}$ of sediment-water incubations, all the surface tracers in the control cores remained at the sediment-water interface (Fig. 2). This observation indicated that particles were not transported downwards (buried) in the absence of animals. It also confirmed that sediment handling, i.e. the freezing/ de-freezing procedure and eventual compaction of the sediment cakes during core construction, did not affect tracer distributions. The deep tracers remained in the $2-2.5 \mathrm{~cm}$ deep layer at the end of the incubation experiment. Fig. 3 shows the distributions of

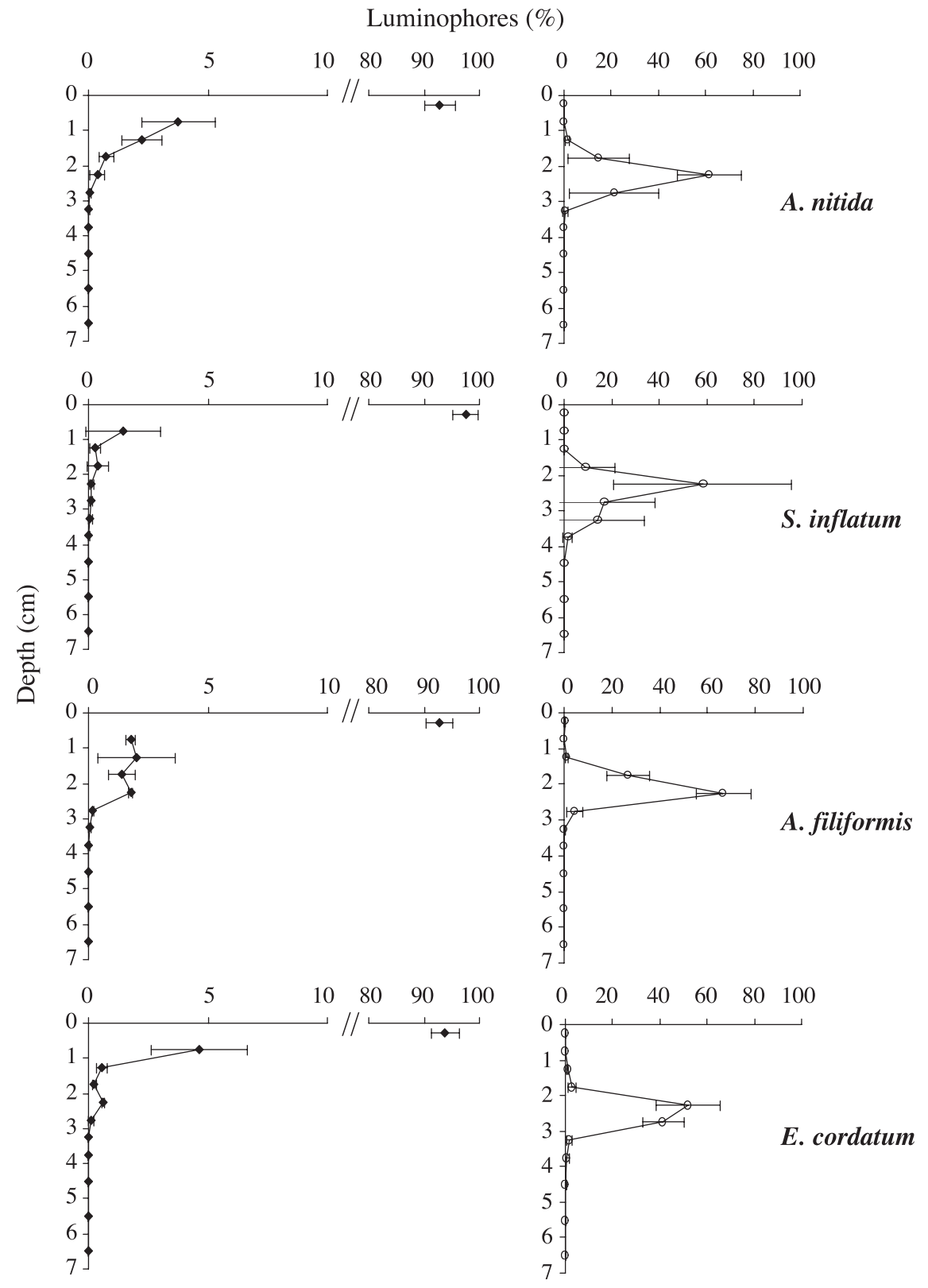

Fig. 4. Luminophore depth profiles in experimental sediments inhabited by Abra nitida, Scalibregma inflatum, Amphiura filiformis and Echinocardium cordatum (surface luminophores: full symbol; deep luminophores: open symbol). 
hydrocarbon compounds in the inhabited cores after 10 days of incubation. Concentrations of $\mathrm{HC}$ deeper than $7 \mathrm{~cm}$ were similar to the background concentrations. Therefore, only the $0-7 \mathrm{~cm}$ zone was considered in the calculations. For clarity reasons, only one tracer profile was plotted (phytane and pristane for the surface and the deep sediment layers, respectively). For each mixture, the three alkanes showed similar distributions.

In the bioturbated sediments, surface hydrocarbons were buried down to $5 \mathrm{~cm}$ depth and more than $99 \%$ were detected within the first $4 \mathrm{~cm}$ (Fig. 3). The depth profiles indicated a rapid burial of surf-HC within 10 $\mathrm{d}$ and 8 to $18 \%$ of surf-HC were buried below the sediment surface layer. The echinoderm E. cordatum was responsible for the highest downward transfer of $\mathrm{HC}$ originally deposited on the sediment surface. Surf$\mathrm{HC}$ concentrations exhibited exponentially decreasing profiles from the surface sediment down to $3.5 \mathrm{~cm}$ depth for the A. nitida, A. filiformis and E. cordatum treatments. In the $S$. inflatum sediment cores, surf-HC concentration rapidly decreased from the surface to 1 $\mathrm{cm}$ depth, followed by constant distributions below 1 $\mathrm{cm}$ depth (Fig. 3). Hydrocarbon tracers deposited in the deeper sediment layers were essentially redistributed in the $1-3.5 \mathrm{~cm}$ sediment layer. However, deep$\mathrm{HC}$ was also detected in the surface layer in one core containing A. filiformis, and down to $5 \mathrm{~cm}$ in the cores reworked by $S$. inflatum. The redistribution of deep$\mathrm{HC}$ typically resulted from biodiffusive-like processes for the four species. However, their distribution was more spread out with $S$. inflatum $(\sim 3 \mathrm{~cm} v s . \sim 2 \mathrm{~cm}$ for the other species) (Fig. 3). Similar depth profiles were obtained for luminophores (Fig. 4).

\subsection{Mixing coefficients}

For each of the four species studied, the mean mixing coefficients ( $D b$ and $r$ ) calculated for all hydrocarbons (surface and deep mixtures) within each core are presented in Table 1.

Quantification of sediment reworking activities ( $D b$ and $r$ ) showed that the transport of surf-HC in our experimental system could be explained by both continuous- $\left(D b_{1}\right)$ and non-continuous transport of tracer $\left(r_{1}\right)$. The transport of deeply deposited tracers was only influenced by a continuous transport $\left(D b_{2}\right)$. $D b_{1}$ ranged between 1.5 and $8.4 \times 10^{-3} \mathrm{~cm}^{2} \mathrm{~d}^{-1}$. In

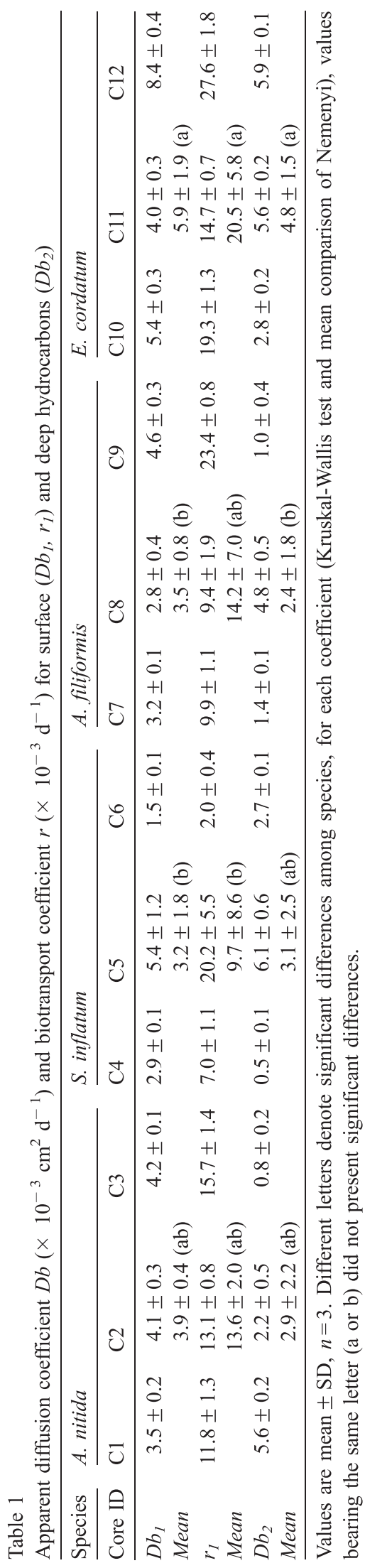


A)

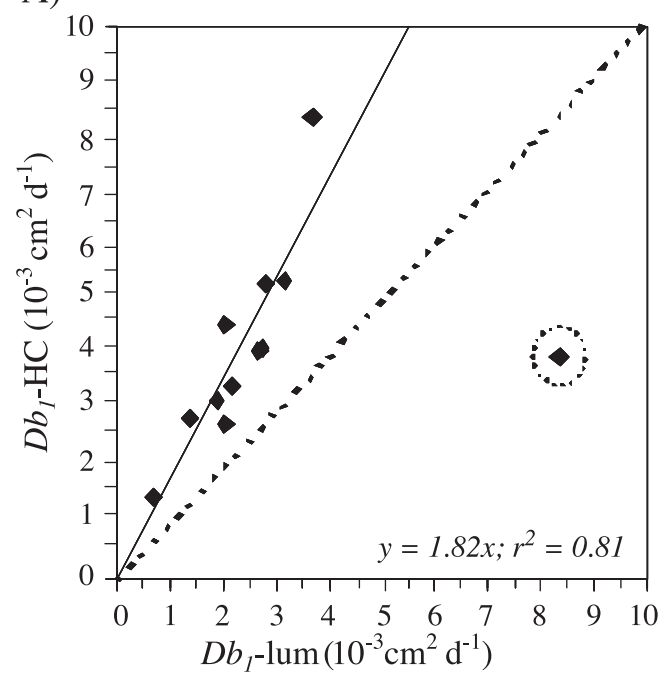

B)

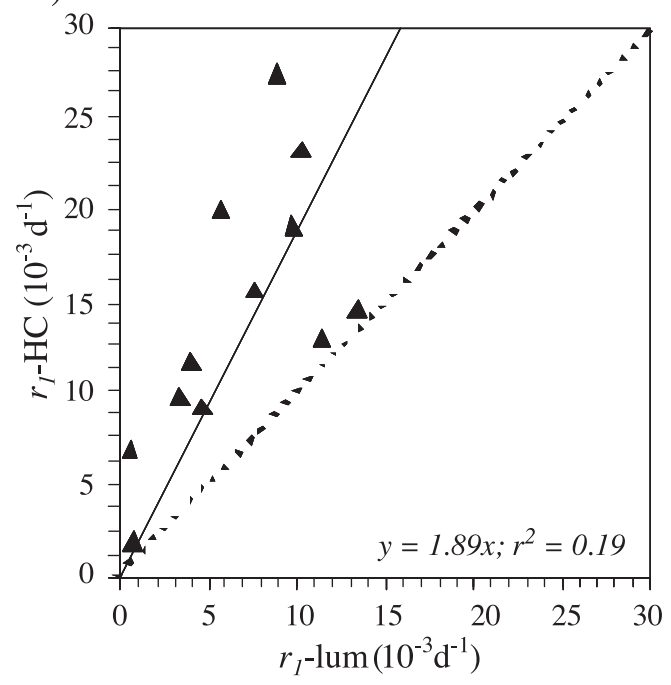

C)

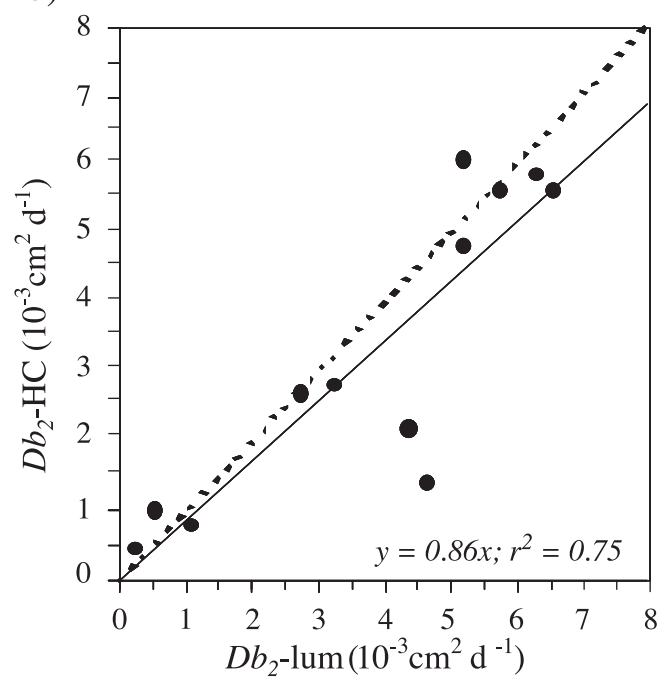

general, the lower mixing coefficients were obtained in the $S$. inflatum cores, while the higher coefficients were calculated in the E. cordatum inhabited cores (Table 1). $r_{1}$ ranged from 2.0 for $S$. inflatum to $27.6 \times 10^{-3} \mathrm{~d}^{-1}$ for E. cordatum (Table 1). $D b_{2}$ ranged from 0.5 to $6.1 \times 10^{-3} \mathrm{~cm}^{2} \mathrm{~d}^{-1}$ (Table 1).

Statistical analysis using the Kruskal-Wallis test showed significant differences in biodiffusion coefficients and biotransport coefficients between the spe$\operatorname{cies}\left(D b_{1}: \mathrm{F}=11.90, \mathrm{P}<0.05 ; r_{1}: \mathrm{F}=11.03, \mathrm{P}<0.05\right.$; $\left.D b_{2}: \mathrm{F}=7.83, \mathrm{P}<0.05\right)$.

A comparison between mixing coefficients calculated from hydrocarbon and luminophores distributions, respectively, revealed that both types of tracers came out with similar mixing coefficients (Fig. 5). $D b_{1}$ and $r_{1}$ were twice those of surface luminophore coefficients (slopes $=1.82$ and 1.89 for $D b_{1}$ and $r_{1}$, respectively). Biodiffusion coefficients $\left(D b_{2}\right)$ for the deep tracers were similar $($ slope $=0.86$ ).

\section{Discussion}

Overall distributions of particles and particle-associated organic compounds in reworked marine sediments generally result from the feedback mechanisms that operate between bioturbation, degradation processes and physical mixing. In this study, hydrocarbon compounds are considered to be conservative organic tracers since their reactivity in marine sediments is normally significantly lower than most other lipid classes (Saliot, 1994; Colombo et al., 1997). This was confirmed by the quantification of $\mathrm{HC}$ which remained constant in the entire sedimentary column throughout the 10-d incubation (Fig. 3). Moreover, the experimental set-up was designed to have no physical disturbance at the sediment-water interface. Therefore, modifications of $\mathrm{HC}$ profiles were only induced by the burrowing and subsequent reworking of benthic macrofauna.

Fig. 5. Comparison between hydrocarbon (y-axis) and luminophore (x-axis) mixing coefficients for the four species. (A) Surface apparent biodiffusion coefficients $\left(D b_{1}\right),(\mathrm{B})$ surface biotransport coefficients $\left(r_{I}\right)$, and (C) deep apparent biodiffusion coefficients $\left(D b_{2}\right)$. Solid lines represent linear correlation and dotted lines 1:1 fits. The encircled point was not taken into account in the linear correlation of surface tracers. 


\subsection{Macrofauna induced redistribution of deposited hydrocarbons}

Among the different species present at the sampling site, A. nitida, A. filiformis, $S$. inflatum and $E$. cordatum were chosen for their demonstrated reworking activities. Although the four species have different functionalities and thus are expected to affect particle transport differently, they all presented a sediment reworking behaviour that includes continuous and non-continuous transport processes. Organic and inorganic particles were not only transported downwards. All four species have been shown to induce upward movements of particles. Unlike conveyor-belt feeders (e.g. oligochaetes) that transport particles from sub-surface to the sediment surface by burrowing into sediments to feed and defecating on the sediment surface (Rhoads, 1974; Robbins et al., 1979), these species do not belong to functional groups known to induce such movements. Such bi-directional sediment reworking thus leads to vertical movement of particles across oxic and anoxic boundaries. The frequency and duration of these processes may significantly influence degradation rates and net preservation of $\mathrm{OM}$ (Aller, 1994).

The sediment reworking of $A$. nitida, $S$. inflatum and $E$. cordatum is normally explained by their feeding activity and their displacements. For example, Wikander (1980) deduced from sediment reworking calculations that the surface deposit feeder $A$. nitida possesses a bioturbating potentiality by picking food with the siphon and moving about in the sediment (Persson and Rosenberg, 2003). A. filiformis stretches its arms above the sediment to feed and can switch between suspension-feeding and deposit-feeding depending on hydrodynamic conditions at the watersediment interface and OM availability (Buchanan, 1964). This species, which rapidly transports sediment down along the arms to the disc $3-4 \mathrm{~cm}$ below the surface (Persson and Rosenberg, 2003), is generally considered to be an efficient sediment reworker (Rosenberg et al., 1997; Solan and Kennedy, 2002; Gilbert et al., 2003b). This was also confirmed in the Gullmar Fjord, where Josefson et al. (2002) showed a rapid burial down to $5 \mathrm{~cm}$ depth of phytodetritus by $A$. filiformis as early as $9 \mathrm{~h}$ after a simulated bloom. Blair et al. (1996) showed that in continental slope sediments dominated by the surface/subsurface deposit- feeder $S$. inflatum, fresh algal material was rapidly transported from the surface down to $4-5 \mathrm{~cm}$ depth. The surface deposit feeder E. cordatum may rapidly transport $\mathrm{OM}$ from the sediment surface deeper into the sediment (Osinga et al., 1997). This species creates a clean, circular spot on the sediment around the opening of its burrow. When the sediment surface is cleared, E. cordatum moves to a new spot (Cramer et al., 1991). Moreover, Sandnes et al. (2000) found that downward transport of an organic contaminant was positively correlated to $E$. cordatum abundance in natural sediments.

In this study, a possible behavioural difference of S. inflatum compared to the other macrofaunal species was suggested (Fig. 3). As visually observed, the polychaete created galleries downward from the surface, and was moving up and down in the surface sediment layers. This was further supported by the positioning of $S$. inflatum individuals in the sediment column at the end of experiments. The polychaete was generally found in the $7-13 \mathrm{~cm}$ zone, whereas the three other species only occupied the 0-9 $\mathrm{cm}$ layer (Gilbert et al., $\mathrm{ms}$ in prep.). This 'gallery-diffusion' activity may therefore actively support reworking of tracers from deeper sediment layers (Figs. 3 and 4).

From a quantitative point of view, significant differences between the four species were demonstrated. Differences in particle mixing efficiency were especially pronounced for E. cordatum. The comparably high mixing coefficients (e.g., $D b_{1}=5.9 \pm$ $1.9 \times 10^{-3} \mathrm{~cm}^{2} \mathrm{~d}^{-1}$; mean $\pm \mathrm{SD} ; n=9$; Table 1$)$ demonstrated that $E$. cordatum was the most efficient sediment reworker in our study. Calculated mixing coefficients and the observation of an efficient particle transport for $E$. cordatum are in agreement with reports by Sandnes et al. (2000), who calculated a $D b$ of $6.3 \times 10^{-3} \mathrm{~cm}^{2} \mathrm{~d}^{-1}$ for a benthic mesocosm population dominated by $E$. cordatum.

\subsection{Comparison of $H C$ with other tracers}

In the present study, the simultaneous use of both hydrocarbons and luminophores as sediment reworking tracers helped us to quantify the processes responsible for particle and hydrocarbon tracer redistribution in the sediment column. The four species investigated had a greater influence ( $\sim 2$ times higher) on surface $\mathrm{HC}$ than on surface luminophores (Fig. 5). Selectivity 
of surface particles as a function of size (Self and Jumars, 1988; Shull and Yasuda, 2001; Giangrande et al., 2002), resulting in an increase of the biodiffusive mixing intensity for smaller particles (Wheatcroft, 1992), may explain the difference observed between tracers deposited on the sediment surface. Indeed, in our experiment, $\mathrm{HC}$ tracers were initially adsorbed on montmorillonite particles smaller than $4 \mu \mathrm{m}$ (clays), whereas the size of the luminophore particles ranged from 100 to $160 \mu \mathrm{m}$.

Overall particle properties (e.g. equilibrium capacity for $\mathrm{OM}$ association) significantly influence the intensity of mixing. Benthic assemblages are suggested to preferentially select high-quality food particles, and thus produce quality-dependent mixing intensities in both coastal and deep areas (Smith et al., 1993; Miller et al., 2000; Fornes et al., 2001; Green et al., 2002). This process, sometimes referred to as 'age-dependent mixing' (Smith et al., 1993; Fornes et al., 2001), mixes food-rich particles into the sediment column faster than older food-poor particles. The burial and sequestration of recently deposited phytodetritus may serve as food buffer for the benthos (Josefson et al., 2002) and therefore slow down OM degradation by removing it from the oxidised layer (Blair et al., 1996; Osinga et al., 1997; Van de Bund et al., 2001).

On the other hand, at depth, no difference in reworking was observed between the two tracers (Fig. 5). As the four species studied fed at the sediment surface, we conclude that deep particle reworking was not related to feeding but rather to animal displacements. In this case, no active selectivity of particles can be observed. However, by remobilising old and refractory buried organic particles deep reworking can re-expose them to oxygen and enhance their degradation (Andersen and Kristensen, 1992; Hulthe et al., 1998; Kristensen and Holmer, 2001).

\section{Conclusions}

Biologically driven transport of particulate tracers was observed and quantified using a diffusion-transport model. Our results demonstrated that the four macrobenthic species, although presenting different feeding ethology and reworking ability, induced a similar redistribution of hydrocarbons in the sediment. Simultaneous upward and downward transport of tracers was recorded, indicating potential effects of these bioturbators on the redistribution of both newly deposited and buried OM in surface sediments. Quantitatively, E. cordatum appeared to be the most efficient species for sediment reworking.

From calculated reworking coefficients obtained from distributions of tracers we conclude that surface reworking was related to feeding activity and deep reworking rather than to animal displacements. In order to assess the impact of macrofauna on OM distribution and fate within an intact benthic community, further studies combining different species are now needed to determine how animal interactions may affect macrobenthic community sediment mixing.

\section{Acknowledgements}

We thank Katja Ringdahl and Birthe Hellman for their skilled assistance in sediment and animal manipulation, Elodie Salmon for her help with hydrocarbon analysis and Jean-Christophe Poggiale for modelling. We are grateful to Gerhard C. Cadée (JSR editor) and anonymous reviewers, who significantly helped us improve the ms. Thanks are also due to the crews of RV 'Oscar von Sydow' and RV 'Arne Tiselius' for their help in the field. This work was supported by the European Commission Human Potential Programme 'Access to Research Infrastructures' to Georges Stora and Franck Gilbert, and realised at the Kristineberg Marine Research Station (Fiskebäckskil, Sweden). Financial support to Stefan Hulth was obtained from the Swedish Natural Science Research Council (VR), the Swedish Engineering Foundation (CF), the Technology Link Foundation in Göteborg (TBSG) and the Foundation for Strategic Environmental Research (MISTRA). This work was part of Franck Gilbert's 'mise à disposition' CNRS programme. Nereis Park contribution number 007.

\section{References}

Aller, R.C., 1994. Bioturbation and remineralization of sedimentary organic matter: effects of redox oscillation. Chem. Geol. 114, $331-345$. 
Aller, R.C., 2001. Transport and reactions in the bioirrigated zone. In: Boudreau, B., Jørgensen, B.B. (Eds.), The Benthic Boundary Layer: Transport processes and biogeochemistry. Oxford Press, pp. 269-301.

Aller, R.C., Aller, J.Y., Kemp, P.F., 2001. Effects of particle and solute transport on rates and extent of remineralization in bioturbated sediments. In: Aller, J.Y., Woodin, S.A., Aller, R.C. (Eds.), Organism-Sediment Interactions. University of South Carolina Press, Columbia, SC, pp. 315-333.

Andersen, F.Ø., Kristensen, E., 1992. The importance of benthic macrofauna in decomposition of microalgae in a coastal marine sediment. Limnol. Oceanogr. 37, 1392-1403.

Berg, P., Rysgaard, S., Funch, P., Sejr, M., 2001. Effects of bioturbation on solutes and solids in marine sediments. Aquat. Microb. Ecol. 26, 81-94.

Berner, R.A., 1980. Early Diagenesis: A Theoretical Approach Princeton University Press, Princeton, New-Jersey.

Bianchi, T.S., Johansson, B., Elmgren, R., 2000. Breakdown of phytoplankton pigments in Baltic sediments: effects of anoxia and loss of deposit-feeding macrofauna. J. Exp. Mar. Biol. Ecol. 251, 161-183.

Blair, N.E., Levin, L.A., DeMaster, D.J., Plaia, G., 1996. The shortterm fate of fresh algal carbon in continental slope sediments. Limnol. Oceanogr. 41, 1208-1219.

Boudreau, B.P., 1986. Mathematics of tracer mixing in sediments: II. Nonlocal mixing and biological conveyor-belt phenomena. Am. J. Sci. 286, 199-238.

Buchanan, J.B., 1964. A comparative study of some features of the biology of Amphiura filiformis and Amphiura chiajei (Ophiuroidea) considered in relation to their distribution. J. Mar. Biol. Assoc. UK 44, 565-576.

Cramer, A., Duineveld, G.C.A., Jenness, M.I., 1991. Observations on spatial distribution, metabolism and feeding strategy of Echinocardium cordatum (Pennant) (Echinodermata) and the implications for its energy budget. In: Cramer, A. (Ed.), Benthic Metabolic Activity at Frontal Systems in the North Sea. Ph.D. Thesis, University of Amsterdam, pp. 63-74.

Colombo, J.C., Silverberg, N., Gearing, J.N., 1997. Lipid biogeochemistry in the Laurentian Trough-II. Changes in composition of fatty acids, sterols and aliphatic hydrocarbons during early diagenesis. Org. Geochem. 26, 257-274.

Fornes, W.L., DeMaster, D.J., Smith, C.R., 2001. A particle introduction experiment in Santa Catalina Basin sediments: Testing the age-dependant mixing hypothesis. J. Mar. Res. 59, 97-112.

François, F., Dalegre, K., Gilbert, F., Stora, G., 1999. Specific variability within functional groups. Study of the sediment reworking of two Veneridae bivalves, Ruditapes decussatus and Venerupis aurea. C. R. Acad. Sci. II 322, 339-345.

François, F., Poggiale, J.-C., Durbec, J.-P., Stora, G., 2001. A new model of bioturbation for a functional approach to sediment reworking resulting from macrobenthic communities. In: Aller, J.Y., Woodin, S.A., Aller, R.C. (Eds.), Organism-Sediment Interactions. University of South Carolina Press, Columbia, SC, pp. 73-86.

François, F., Gérino, M., Stora, G., Durbec, J.-P., Poggiale, J.-C., 2002. Functional approach to sediment reworking by galleryforming macrobenthic organisms: modelling and application with the polychaete Nereis diversicolor. Mar. Ecol. Prog. Ser. 229, $127-136$.

Gérino, M., Aller, R.C., Lee, C., Cochran, J.K., Aller, J.Y., Green, M.A., Hirschberg, D., 1998. Comparison of different tracers and methods used to quantify bioturbation during a spring bloom: 234-Thorium, luminophores and chlorophyll $a$. Estuar. Coast. Shelf Sci. 46, 531-547.

Giangrande, A., Montresor, M., Cavallo, A., Licciano, M., 2002. Influence of Naineris laevigata (Polychaeta: Orbiniidae) on vertical grain size distribution, and dinoflagellate resting stages in the sediment. J. Sea Res. 47, 97-108.

Gilbert, F., Stora, G., Bertrand, J.-C., 1996. In situ bioturbation and hydrocarbon fate in an experimental contaminated Mediterranean coastal ecosystem. Chemosphere 33, 1449-1458.

Gilbert, F., Hulth, S., Aller, R.C., 2003a. The influence of macrofaunal burrow spacing and diffusive scaling on sedimentary nitrification and denitrification: An experimental and model approach. J. Mar. Res. 61, 101-125.

Gilbert, F., Hulth, S., Strömberg, N., Ringdahl, K., Poggiale, J.-C., 2003b. 2-D optical quantification of particle reworking activities in marine surface sediments. J. Exp. Mar. Biol. Ecol. 285-286, $251-263$.

Gilbert, F., Caradec, S., Ringdahl, K., Poggiale, J.-C., Hulth, S., Desrosiers, G., Rosenberg, R., Stora, G. Comparison of sediment reworking by four macrobenthic species of the Gullmar Fjord (western coast Sweden). In prep.

Green, M.A., Aller, R.C., Cochran, J.K., Lee, C., Aller, J.Y., 2002. Bioturbation in shelf/slope sediments off Cape Hatteras, North Carolina: the use of ${ }^{234} \mathrm{Th}, \mathrm{Chl}-a$, and $\mathrm{Br}$ - to evaluate rates of particle and solute transport. Deep-Sea Res. II 49, 4627-4644.

Grossi, V., Caradec, S., Gilbert, F., 2003. Burial and reactivity of sedimentary microalgal lipids in bioturbated Mediterranean coastal sediments. Mar. Chem. 81, 57-69.

Hulthe, G., Hulth, S., Hall, P.O.J., 1998. Effect of oxygen on degradation rate of refractory and labile organic matter in continental margin sediments. Geochim. Cosmochim. Acta 62, 1319-1328.

Ingalls, A.E., Aller, R.C., Lee, C., Sun, M.-Y., 2000. The influence of deposit-feeding on chlorophyll- $a$ degradation in coastal marine sediments. J. Mar. Res. 58, 631-651.

Josefson, A.B., Forbes, T.L., Rosenberg, R., 2002. Fate of phytodetritus in marine sediments: functional importance of macrofaunal activity. Mar. Ecol. Prog. Ser. 230, 71-85.

Kristensen, E., 2001. Impact of polychaetes (Nereis spp. and Arenicola marina) on carbon biogeochemistry in coastal marine sediments. Geochem. Transactions 12, 92-103.

Kristensen, E., Blackburn, T.H., 1987. The fate of organic carbon and nitrogen in experimental marine sediment systems: Influence of bioturbation and anoxia. J. Mar. Res. 45, 231-257.

Kristensen, E., Holmer, M., 2001. Decomposition of plant materials in marine sediment exposed to different electron acceptors $\left(\mathrm{O}_{2}\right.$, $\mathrm{NO}_{3}$ and $\mathrm{SO}_{4}^{2-}$ ), with emphasis on substrate origin, degradation kinetics, and the role of bioturbation. Geochim. Cosmochim. Acta 65, 419-433.

Middelburg, J.J., Barranguet, C., Boschker, H.T.S., Herman, P.M.J., Moens, T., Heip, C.H.R., 2000. The fate of intertidal microphytobenthos carbon: an in situ ${ }^{13} \mathrm{C}$-labelling study. Limnol. Oceanogr. 45, 1224-1234. 
Miller, R.J., Smith, C.R., DeMaster, D.J., Fornes, W.L., 2000. Feeding selectivity and rapid particle processing by deep-sea megafaunal deposit feeders: ${ }^{234}$ Th tracer approach. J. Mar. Res. 58, $653-673$

Osinga, R., Kop, A.J., Malschaert, J.F.P., Van Duyl, F.C., 1997. Effects of the sea urchin Echinocardium cordatum on bacterial production and carbon flow in experimental benthic systems under increasing organic loading. J. Sea Res. 37, 109-121.

Persson, A., Rosenberg, R., 2003. Impact of grazing and bioturbation of marine benthic deposit feeders on dinoflagellate cysts. Harmful Algae 2, 43-50.

Reise, K., 2002. Sediment mediated species interactions in coastal waters. J. Sea Res. 48, 127-141.

Rhoads, D.C., 1974. Organism-sediment, relations on the muddy sea floor. Oceanogr. Mar. Biol. Ann. Rev. 12, 263-300.

Robbins, J.A., McCall, P.L., Fisher, J.B., Krezoski, J.R., 1979. Effect of deposit feeders on migration of 137Cs in lake sediments. Earth Planet. Sci. 42, 277-287.

Rosenberg, R., Nilsson, H.C., Hollertz, K., Hellman, B., 1997. Density-dependent migration in an Amphiura filiformis (Amphiuridae, Echinodermata) infaunal population. Mar. Ecol. Prog. Ser. $159,121-131$.

Saliot, A., 1994. Les lipides, leur rôle biochimique et leur utilisation comme marqueurs biogéochimiques. Biogéochimie organique marine. Institut Océanographique, Paris, pp. 137-197.

Sandnes, J., Forbes, T., Hansen, R., Sandnes, B., 2000. Influence of particle type and faunal activity on mixing of di(2-ethylhexyl)phtalate (DEHP) in natural sediments. Mar. Ecol. Prog. Ser. $197,151-167$
Self, R.F.L., Jumars, P.A., 1988. Cross-phyletic patterns of particle selection by deposit feeders. J. Mar. Res. 46, 119-143.

Shull, D., Yasuda, M., 2001. Size-selective downward particle transport by cirratulid polychaetes. J. Mar. Res. 59, 453-473.

Smith, C.R., Pope, R.H., DeMaster, D.J., Magaard, L., 1993. Agedependant mixing of deep-sea sediments. Geochim. Cosmochim. Acta 57, 1473-1488.

Solan, M., Kennedy, R., 2002. Observation and quantification of in situ animal-sediment relations using time-lapse sediment profile imagery (t-SPI). Mar. Ecol. Prog. Ser. 228, 179-191.

Sun, M.-Y., Aller, R.C., Lee, C., Wakeham, S.G., 1999. Enhanced degradation of algal lipids by benthic macrofaunal activity: effect of Yoldia limatula. J. Mar. Res. 57, 775-804.

Van de Bund, W.J., Olafsson, E., Modig, H., Elmgren, R., 2001. Effects of the coexisting Baltic amphipods Monoporeia affinis and Pontoporeia femorata on the fate of a simulated spring diatom bloom. Mar. Ecol. Prog. Ser. 22, 107-115.

Webb, D.G., Montagna, P.A., 1993. Initial burial and subsequent degradation of sedimented phytoplankton: relative impact of macrofauna and meiobenthos. J. Exp. Mar. Biol. Ecol. 166, $151-163$.

Wheatcroft, R.A., 1992. Experimental tests for particle size-dependant bioturbation in the deep ocean. Limnol. Oceanogr. 37, 90-104.

Wikander, P.B., 1980. Quantitative aspects of deposit feeding in Abra nitida (Müller) and A. longicallus (Scacchi) (Bivalvia, Tellinacea). Sarsia 66, 35-48.

Zar, J.H., 1999. Biostatistical Analysis, 4th Ed. Prentice-Hall, Upper Saddle River. 